\title{
Development of Learning Instructional Based On 3R (Reduce, Reuse, \& Recycle) to Improve Learning's Outcome on Fourth Grade of Elementary School on Environmental Preservation's Material
}

\author{
Priliya Dwi Nurisdiana $^{1}$ Z.A. Imam Supardi ${ }^{2}$ Sifak Indana $^{3}$ \\ Graduate Program of Elementary Education Department, \\ Universitas Negeri Surabaya
}

\begin{abstract}
This study aims to (1) produce learning instructional based on $3 R$ that is valid, practical, and effective to improve learning's outcome of elementary school fourth grade students, (2) describe the validity, practicality, and effectiveness of learning instructional based on 3R to improve student learning's outcome on Themes 4 Sub Theme 1 Learning 1.
\end{abstract}

This research is a study of the development of learning instructional using the 4-D development model. Learning instructional based on $3 R$ are validated by experts in their fields. The validation results state that learning instructional can be applied. The validated learning instructional was tested on fourth grade students at SDN Wonokusumo I/40 Surabaya.

The results of limited trials show that (1) The learning instructional developed get very valid categories, (2) Practical learning instructional based on the feasibility of lesson plans with very good categories and active students in learning activities, (3) Learning instructional are declared effective based on domain learning's outcome knowledge who get completeness of $88.2 \%$, in the attitude domain get results $90 \%$ of students have very good attitude, and completeness of $85.3 \%$ in the skill domain, and get excellent student responses.

Thus it can be concluded that learning instructional based on $3 R$ are valid, practical, and effective to be used to improve learning's outcome of $4^{\text {th }}$ grade elementary school students on environmental preservation's material.

Keywords:- Learning Instructional, 3R (Reduce, Reuse, and Recycle), Learning's Outcome.

\section{INTRODUCTION}

The problem of waste is one of the problems that until now has not been resolved. The amount of garbage is increasing every day. Most of the waste is inorganic waste that takes a long time to decompose. Inorganic waste is dominated by plastic waste originating from food or beverage packaging of a product and plastic bag. Plastic waste can pollute the environment if it is not treated properly. Plastics contain toxic additives, coloring agents, and are also not environmentally friendly. Organic chemicals such as dissolved plastics can cause death in fish and other aquatic organisms (Darmono, 2006).

At present there is a vigorous implementation of plastic waste management by implementing environmentally friendly life. These activities can be carried out through the use of waste into goods that have use value as an effort to preserve the environment $3 R$, namely Reduce, Reuse, and Recycle. 3R activities up to now are still the best way to manage and handle waste with a variety of problems. Waste management with the $3 \mathrm{R}$ system can be implemented by everyone in their daily activities.

Based on the results of observations, the results showed that environmental preservation activities for fourth grade students of SDN Wonokusumo I/40 Surabaya had gone quite well. This is because students are actively involved in maintaining cleanliness and environmental sustainability. Scheduled students have already carried out the "Ngosek Bersama" activity, community service, and activities that support zero waste. In addition, students also have a responsibility to maintain class cleanliness and care for plants in the classroom environment. But another fact was found, namely that there were still many trash piles in the trash and not infrequently there were still many students who did not care about the environment. The increasing amount of waste is a problem that still cannot be found a solution.

Meanwhile, based on the results of interviews with fourth grade teachers in SDN Wonokusumo I/40 Surabaya, data on student learning's outcome in science subjects were obtained in environmental conservation material, which amounted to 71,5 . This shows that the learning's outcome 
of class IV students are still considered low because they obtain grades under the minimum completion criteria that have been set by the school, which is 75 in science subjects.

Based on the problems found in fourth grade students of SDN Wonokusumo I/40 Surabaya, 3R activities are suitable to be inserted in learning activities. This is because 3R-based learning will be able to improve student learning's outcome on environmental preservation material. Therefore the researcher wants to conduct a research "Development of Learning Instruction Based on 3R (Reduce, Reuse, \& Recycle) to Improve Learning's Outcome on Fourth Grade of Elementary School on Environmental Preservation's Material".

\section{METHOD}

This research is a development research using a 4-D model without the dissimination stage. This study developed learning instructional based on 3R (Reduce, Reuse, and Recycle) to improve the learning's outcome of 4th grade elementary school students on environmental preservation materials.

The study was conducted at SDN Wonokusumo I/40 Surabaya in $4^{\text {th }}$ A 2018/2019 school year, which amounted to 34 students, consisting of 15 male students and 19 female students.

Trial of learning instructional developed using One Group Pretest-Posttest Design. The trial design in this study using one group will be given a pretest and posttest after being treated. The research design by Fraenkel, Wallen, and Hyun (2012) is described as follows:

\begin{tabular}{|ccc|}
\hline Pretest & Treatment & Posttest \\
$0_{1}$ & $\mathrm{X}$ & $\mathrm{O}_{2}$ \\
\hline
\end{tabular}

Fig 1

Data analysis techniques are carried out to process data obtained from the results of trials so that the learning instructional used in learning activities can be known validity, practicality, and effectiveness. Data from the research results analyzed include the validity of learning instructional, learning's outcome tests, student response questionnaires, readability of teaching materials, observation sheet of lesson plan implementation, student activity sheets, and obstacles that arise during learning activities follows:

Data from the research results to be analyzed are as

\section{A. Analysis of Learning instructional Validation Results}

Validation of learning instructional consists of Syllabus, Lesson Plan, Teaching Materials, Student Activity Sheets, and Learning's Outcome Test. The results of the validation of the learning instructional were then analyzed in quantitative descriptive, by calculating the average score of the assessment from the validator. The average score obtained is converted using the following conditions:

\begin{tabular}{|c|c|c|}
\hline Validation Score Interval & Category & Information \\
\hline $3,6 \leq \mathrm{SV}<4$ & Very Valid & Can be used without revision \\
\hline $2,6 \leq \mathrm{SV}<3,5$ & Valid & Can be used with a slight revision \\
\hline $1,6 \leq \mathrm{SV}<2,5$ & Less Valid & Can be used with many revisions \\
\hline $0,6 \leq \mathrm{SV}<1,5$ & Invalid & Cannot be used, it still requires consultation \\
\hline
\end{tabular}

Table 1:- Criteria for categorizing the validity of learning instructional

(Ratumanan \& Laurens, 2011)

\section{B. Readability Analysis of Teaching Materials}

The reading of teaching materials is done by filling out the questionnaire and to measure the readability of teaching materials the following formula is used.

$$
\mathrm{P}=\frac{\sum K}{\sum N} \mathrm{x} 100 \%
$$

Information:

$\mathrm{P} \quad=$ Readability percentage

$\sum \mathrm{K}=$ Number of students who choose yes or no answers

$\sum \mathrm{N}=$ Number of students who fill in the questionnaire

\section{Analysis of Lesson Plan}

Data on the implementation of the lesson plan was analyzed descriptively quantitatively, namely by calculating the score of the observations and then looking for percentages related to the implementation of the learning stages in the lesson plan carried out by the teacher during the learning activities. Calculation of the percentage of implementation of lesson plan is calculated using the following formula:

$$
\begin{aligned}
& \text { the number of settlement lesson plan that were } \\
& \mathrm{P}=\frac{\text { successfully implemented }}{\text { the total stages of the lesson plan }} \times 100 \%
\end{aligned}
$$


Information:

$\mathrm{P}=$ Percentage of Implementation from Lesson Plan
The criteria related to the percentage of implementation of the lesson plan use the provisions in the table below.

\begin{tabular}{|c|c|}
\hline Interval & Category \\
\hline $0 \% \leq \mathrm{P} \leq 25 \%$ & Not implemented \\
\hline $25 \% \leq \mathrm{P} \leq 50 \%$ & Poorly implemented \\
\hline $50 \% \leq \mathrm{P} \leq 75 \%$ & Well done \\
\hline $75 \% \leq \mathrm{P} \leq 100 \%$ & Very well done \\
\hline
\end{tabular}

Table 2:- Criteria for Percentage of Implementation of Lesson Plan

(Riduwan, 2012)

\section{Analysis of Student Activities}

Student activity data is taken from student activities seen during the learning activities. The percentage of student activity is calculated using the following formula.

$$
\mathrm{P}=\frac{\mathrm{TSe}}{\mathrm{N}} \times 100 \%
$$

Information:

$\mathrm{P}=$ = Percentage of Student Activities

Tse $=$ Number of activities shown by students

$\mathrm{N} \quad=$ Number of all activities

(Akbar, 2012)

E. Analysis of Learning's Outcome Tests
In determining the improvement of student learning's outcome, used Normalized Gain student learning's outcome. The increase or gain is calculated using the following formula.

$$
\mathrm{g}=\frac{\left(s_{\text {post }}\right)-\left(s_{\text {pre }}\right)}{\text { skormax }-\left(s_{\text {pre }}\right)}
$$

Information:

g $($ gain $)=$ Increased Learning's outcome

$\mathrm{S}_{\text {pre }} \quad=$ Pretest score (initial learning result)

$\mathrm{S}_{\text {post }} \quad=$ Posttest score (final learning result) (Hake, 1999)

The categories related to gain scores refer to the following table.

\begin{tabular}{|c|c|}
\hline n-gain & Category \\
\hline$(\mathrm{g})>0,7$ & High \\
\hline $0,7 \geq(\mathrm{g}) \leq 0,3$ & Medium \\
\hline$(\mathrm{g})<0,3$ & Low \\
\hline
\end{tabular}

Table 3:- N-gain category

\section{RESULTS AND DISCUSSION}

The validity of the developed learning instructional is obtained from the validity of the validator. With the following description, the syllabus has a very valid category with a percentage of agreement of $91.8 \%$, lesson plan has a very valid category with a percentage of agreement of $95.9 \%$, teaching materials that have a very valid category with a percentage of agreement of $89.6 \%$, student activity sheets has a very valid category with a percentage of agreement of $95.9 \%$. Meanwhile knowledge learning's outcome test developed has a very valid category with a percentage of agreement on aspects of content validation at $98.1 \%$, while $96.2 \%$ on aspects of language and question writing. Attitude domain learning test results get a very valid category with a percentage of agreement of 91.4\% and skill domain learning's outcome tests get a valid category with a percentage of agreement of $89.3 \%$.
The practicality of learning instructional is seen based on the implementation of lesson plan in learning activities. The implementation of the learning instructional was observed by two observers in 3 meetings. All stages of activities listed in the lesson plan were carried out in the trial with percentage of agreement amounting to $92.9 \%$ with a very good category. The activities of students get a very good category with the percentage of student activities amounting to $86.3 \%$. While the readability of teaching materials generally gets a positive response from students of $93.25 \%$.

Meanwhile, to measure the effectiveness of learning instructional, learning test results are used. Learning's outcome tests are given to students before learning activities in the form of pretest questions and after learning activities in the form of posttest questions. The results obtained from the pretest and posttest are presented in table 4 below. 
ISSN No:-2456-2165

\begin{tabular}{|c|c|c|c|c|c|c|}
\hline \multirow{2}{*}{ Student's Code } & \multicolumn{2}{|c|}{ Pretest } & \multicolumn{2}{|c|}{ Posttest } & \multirow[b]{2}{*}{$\mathrm{N}$-gain } & \multirow{2}{*}{$\mathbf{K}$. } \\
\hline & Value & Ket. & Value & Ket. & & \\
\hline S1 & 80 & $\mathrm{~T}$ & 100 & $\mathrm{~T}$ & 1.0 & High \\
\hline S2 & 80 & $\mathrm{~T}$ & 100 & $\mathrm{~T}$ & 1.0 & High \\
\hline S3 & 67 & TT & 93 & $\mathrm{~T}$ & 0.8 & High \\
\hline S4 & 40 & TT & 93 & $\mathrm{~T}$ & 0.9 & High \\
\hline S5 & 47 & TT & 100 & $\mathrm{~T}$ & 1.0 & High \\
\hline S6 & 33 & TT & 93 & $\mathrm{~T}$ & 0.9 & High \\
\hline S7 & 40 & TT & 80 & TT & 0.7 & High \\
\hline S8 & 47 & TT & 80 & $\mathrm{~T}$ & 0.6 & Medium \\
\hline S9 & 40 & TT & 87 & $\mathrm{~T}$ & 0.8 & High \\
\hline S10 & 27 & TT & 67 & TT & 0.5 & Medium \\
\hline S11 & 67 & TT & 100 & $\mathrm{~T}$ & 1.0 & High \\
\hline S12 & 53 & TT & 87 & $\mathrm{~T}$ & 0.7 & High \\
\hline S13 & 60 & TT & 93 & $\mathrm{~T}$ & 0.8 & High \\
\hline S14 & 60 & TT & 93 & $\mathrm{~T}$ & 0.8 & High \\
\hline S15 & 27 & TT & 93 & $\mathrm{~T}$ & 0.9 & High \\
\hline S16 & 80 & $\mathrm{~T}$ & 100 & $\mathrm{~T}$ & 1.0 & High \\
\hline S17 & 60 & TT & 93 & $\mathrm{~T}$ & 0.8 & High \\
\hline S18 & 33 & TT & 80 & $\mathrm{~T}$ & 0.7 & High \\
\hline S19 & 80 & $\mathrm{~T}$ & 93 & $\mathrm{~T}$ & 0.7 & High \\
\hline S20 & 80 & $\mathrm{~T}$ & 100 & $\mathrm{~T}$ & 1.0 & High \\
\hline S21 & 33 & TT & 93 & $\mathrm{~T}$ & 0.9 & High \\
\hline S22 & 47 & TT & 93 & $\mathrm{~T}$ & 0.9 & High \\
\hline $\mathrm{S} 23$ & 73 & TT & 100 & $\mathrm{~T}$ & 1.0 & High \\
\hline S24 & 53 & TT & 100 & $\mathrm{~T}$ & 1.0 & High \\
\hline S25 & 27 & TT & 67 & TT & 0.5 & Medium \\
\hline S26 & 67 & TT & 100 & $\mathrm{~T}$ & 1.0 & High \\
\hline S27 & 33 & TT & 73 & TT & 0.6 & Medium \\
\hline S28 & 67 & TT & 87 & $\mathrm{~T}$ & 0.6 & Medium \\
\hline S29 & 47 & TT & 80 & $\mathrm{~T}$ & 0.6 & Medium \\
\hline S30 & 80 & $\mathrm{~T}$ & 93 & $\mathrm{~T}$ & 0.7 & High \\
\hline S31 & 27 & TT & 93 & $\mathrm{~T}$ & 0.9 & High \\
\hline S32 & 33 & TT & 93 & $\mathrm{~T}$ & 0.9 & High \\
\hline S33 & 33 & TT & 87 & $\mathrm{~T}$ & 0.8 & High \\
\hline S34 & 33 & TT & 80 & $\mathrm{~T}$ & 0.7 & High \\
\hline \multicolumn{2}{|c|}{$\begin{array}{l}\text { The number of students who did } \\
\text { not complete }\end{array}$} & 28 & \multicolumn{2}{|c|}{$\begin{array}{l}\text { The number of students who } \\
\text { did not complete }\end{array}$} & \multicolumn{2}{|c|}{4} \\
\hline \multicolumn{2}{|c|}{$\begin{array}{c}\text { The number of students who } \\
\text { complete }\end{array}$} & 6 & \multicolumn{2}{|c|}{$\begin{array}{c}\text { The number of students who } \\
\text { complete }\end{array}$} & \multicolumn{2}{|c|}{30} \\
\hline \multicolumn{2}{|c|}{ Percentage of completeness (\%) } & $17,6 \%$ & \multicolumn{2}{|c|}{$\begin{array}{c}\text { Percentage of completeness } \\
(\%)\end{array}$} & \multicolumn{2}{|c|}{$88,2 \%$} \\
\hline
\end{tabular}

Table 4:- Result of Pretest and Posttest

Information:

$$
\begin{array}{ll}
\mathrm{T} & =\text { Complete } \\
\mathrm{TT} & =\text { Incomplete } \\
\text { Ket. } & = \\
\text { Information } & \\
\mathrm{K} & =\text { Category }
\end{array}
$$

The minimum completion criteria set at $4^{\text {th }}$ SDN Wonokusumo I/40 Surabaya in $4^{\text {th }}$ grade is 75 . In table 4 shows that the percentage of mastery learning at pretest is $17.6 \%$, which means that most students have not reached the specified minimum completion criteria. Meanwhile after the implementation of learning activities by applying learning instructional based on 3R (Reduce, Reuse, and
Recycle), there was an increase in the percentage of completeness, $88.2 \%$ of students who achieved minimum completion criteria were seen from the posttest results.

Learning's outcome in the attitude domain are given to students in the form of filling in the self-assessment sheet by each student. The acquisition of student learning's outcome in the attitude domain is divided into two, namely spiritual attitudes and social attitudes. In the spiritual attitude, results show that $90 \%$ of students have very good attitude. Whereas in the social aspect, it was found that $85 \%$ of students had good attitude, so it could be concluded that the majority of students had attitude categories both on spiritual attitudes and social attitudes. 
Learning's outcome in the skill domain are obtained from the assessment of posters that have been made by students in groups during learning activities. The results obtained from are presented in the following table.

\begin{tabular}{|c|c|c|c|c|c|c|c|}
\hline \multirow[b]{2}{*}{ Student's Code } & \multicolumn{3}{|c|}{ Rated Aspect } & \multirow[b]{2}{*}{ Score } & \multirow[b]{2}{*}{ Value } & \multirow[b]{2}{*}{$\mathbf{K}$} & \multirow[b]{2}{*}{ Ket. } \\
\hline & $\begin{array}{c}\text { Poster } \\
\text { Contents }\end{array}$ & Poster Clarity & $\begin{array}{l}\text { Complete of Poster } \\
\text { Information }\end{array}$ & & & & \\
\hline $\mathrm{S} 1$ & 4,0 & 4,0 & 3,0 & 11,0 & 91,7 & SB & $\mathrm{T}$ \\
\hline $\mathrm{S} 2$ & 2,0 & 3,0 & 3,0 & 8,0 & 66,7 & $\mathrm{C}$ & TT \\
\hline S3 & 2,0 & 3,0 & 3,0 & 8,0 & 66,7 & $\mathrm{C}$ & TT \\
\hline S4 & 4,0 & 3,0 & 4,0 & 11,0 & 91,7 & SB & $\mathrm{T}$ \\
\hline S5 & 4,0 & 3,0 & 4,0 & 11,0 & 91,7 & SB & $\mathrm{T}$ \\
\hline S6 & 4,0 & 4,0 & 3,0 & 11,0 & 91,7 & SB & $\mathrm{T}$ \\
\hline S7 & 4,0 & 3,0 & 3,0 & 10,0 & 83,3 & $\mathrm{~B}$ & $\mathrm{~T}$ \\
\hline S8 & 2,0 & 3,0 & 3,0 & 8,0 & 66,7 & $\mathrm{C}$ & $\mathrm{TT}$ \\
\hline S9 & 4,0 & 3,0 & 3,0 & 10,0 & 83,3 & $\mathrm{~B}$ & $\mathrm{~T}$ \\
\hline S10 & 2,0 & 3,0 & 3,0 & 8,0 & 66,7 & $\mathrm{C}$ & TT \\
\hline S11 & 4,0 & 4,0 & 3,0 & 11,0 & 91,7 & SB & $\mathrm{T}$ \\
\hline S12 & 4,0 & 4,0 & 3,0 & 11,0 & 91,7 & SB & $\mathrm{T}$ \\
\hline S13 & 4,0 & 3,0 & 4,0 & 11,0 & 91,7 & SB & $\mathrm{T}$ \\
\hline S14 & 4,0 & 4,0 & 3,0 & 11,0 & 91,7 & SB & $\mathrm{T}$ \\
\hline S15 & 4,0 & 3,0 & 4,0 & 11,0 & 91,7 & SB & $\mathrm{T}$ \\
\hline S16 & 4,0 & 4,0 & 3,0 & 11,0 & 91,7 & SB & $\mathrm{T}$ \\
\hline S17 & 4,0 & 4,0 & 3,0 & 11,0 & 91,7 & SB & $\mathrm{T}$ \\
\hline S18 & 2,0 & 3,0 & 3,0 & 8,0 & 66,7 & $\mathrm{C}$ & $\mathrm{TT}$ \\
\hline S19 & 4,0 & 3,0 & 4,0 & 11,0 & 91,7 & SB & $\mathrm{T}$ \\
\hline S20 & 4,0 & 3,0 & 3,0 & 10,0 & 83,3 & $\mathrm{~B}$ & $\mathrm{~T}$ \\
\hline S21 & 4,0 & 4,0 & 3,0 & 11,0 & 91,7 & SB & $\mathrm{T}$ \\
\hline S22 & 4,0 & 4,0 & 3,0 & 11,0 & 91,7 & SB & $\mathrm{T}$ \\
\hline S23 & 4,0 & 3,0 & 4,0 & 11,0 & 91,7 & SB & $\mathrm{T}$ \\
\hline S24 & 4,0 & 3,0 & 4,0 & 11,0 & 91,7 & SB & $\mathrm{T}$ \\
\hline S25 & 4,0 & 3,0 & 3,0 & 10,0 & 83,3 & $\mathrm{~B}$ & $\mathrm{~T}$ \\
\hline S26 & 4,0 & 3,0 & 3,0 & 10,0 & 83,3 & $\mathrm{~B}$ & $\mathrm{~T}$ \\
\hline S27 & 4,0 & 3,0 & 4,0 & 11,0 & 91,7 & SB & $\mathrm{T}$ \\
\hline S28 & 4,0 & 3,0 & 3,0 & 10,0 & 83,3 & $\mathrm{~B}$ & $\mathrm{~T}$ \\
\hline S29 & 4,0 & 3,0 & 4,0 & 11,0 & 91,7 & SB & $\mathrm{T}$ \\
\hline S30 & 4,0 & 3,0 & 3,0 & 10,0 & 83,3 & $\mathrm{~B}$ & $\mathrm{~T}$ \\
\hline S31 & 4,0 & 4,0 & 3,0 & 11,0 & 91,7 & SB & $\mathrm{T}$ \\
\hline S32 & 4,0 & 3,0 & 3,0 & 10,0 & 83,3 & $\mathrm{~B}$ & $\mathrm{~T}$ \\
\hline S33 & 4,0 & 3,0 & 3,0 & 10,0 & 83,3 & $\mathrm{~B}$ & $\mathrm{~T}$ \\
\hline S34 & 4,0 & 3,0 & 3,0 & 10,0 & 83,3 & $\mathrm{~B}$ & $\mathrm{~T}$ \\
\hline \multicolumn{5}{|c|}{ The number of students who did not complete } & \multicolumn{3}{|c|}{5} \\
\hline \multicolumn{5}{|c|}{ The number of students who complete } & \multicolumn{3}{|c|}{29} \\
\hline \multicolumn{5}{|c|}{ Percentage of completeness } & \multicolumn{3}{|c|}{$85,3 \%$} \\
\hline
\end{tabular}

Table 5:- Learning's outcome of Skill Domain

Information:

$\begin{array}{llll}\mathrm{K} & = & \text { Ket } & = \\ \text { Category } & & & \text { Information } \\ \text { SB } & =\quad \text { Very } & \text { T } & =\text { Complete } \\ \text { Good } & & \text { TT } & = \\ \mathrm{B} & =\text { Good } & \text { Incomplete } \\ \mathrm{C} & =\text { Enough } & \end{array}$

Based on the data in table 5 , the results show that $85.3 \%$ of students have achieved minimum completion criteria in the skill domains learning's outcome. This shows that most students can participate in learning activities well and can achieve learning goals.

The response of the students in question is students towards learning activities by applying learning instructional based on 3R. Student responses are measured using a questionnaire given when learning activities end. The results of student responses by applying the 3R-based learning instructional in $4^{\text {th }}$ grade SDN Wonokusumo I/40 Surabaya generally received a very good response with the percentage of student responses of $94 \%$. This shows that overall learning activities by implementing learning 
instructional based on $3 \mathrm{R}$ can attract students motivation in learning activities.

\section{CONCLUSION}

The validity of the learning instructional developed is seen from the results of the validity carried out by the validator. The learning instructional developed was declared valid and feasible to use after getting advice and input from the validator. The practicality of the learning instructional developed can be seen from the implementation of the lesson plan, as a whole the learning activities went very well. The most dominant student activity in 3R-based learning activities is working with group members. While the obstacles found when research can be overcome through discussion with observers.

The practicality of learning instructional based on $3 \mathrm{R}$ (Reduce, Reuse, and Recycle) in the study was declared practical based on the feasibility of lesson plans, student activities, student responses, and readability of teaching materials. The implementation of learning received a very good category with a percentage of agreement of $92.9 \%$. The activities of students get a very good category with the percentage of student activities amounting to $86.3 \%$. While the readability of teaching materials generally gets a positive response from students of $93.25 \%$.

The effectiveness of the learning instructional developed can be seen from the completeness of the learning's outcome of student learning's outcome tests in the knowledge realm of obtaining completeness of $88.2 \%$, the attitude domain obtaining $90 \%$ of students having very good attitude, and $85.3 \%$ of students achieving minimum completion criteria in the results learning skill realm. Meanwhile the responses of students get a very good category with the percentage of students' responses amounting to $94 \%$.

Based on the findings of the research results it can be concluded that the learning instructional based on $3 \mathrm{R}$ (Reduce, Reuse, and Recycle) that are developed are feasible to improve student learning's outcome.

\section{SUGGESTION}

Based on the results of the research that has been carried out, there are several suggestions as follows.

Need evaluation in managing time allocation in learning activities.

$>$ The development of learning instructional based on 3R (Reduce, Reuse, and Recycle) needs to be developed and implemented consistently.

\section{REFERENCES}

[1]. Akbar, Sa'dun. 2013. Instrumen Perangkat Pembelajaran. Bandung: Rosdakarya.

[2]. Darmono. 2006. Lingkungan Hidup dan Pencemaran : Hubungannya dengan Toksikologi Senyawa Logam. Jakarta: UI - Press.

[3]. Fraenkel, J.R., Wallen, N. E., Hyun, H. (2012). How to Design and Evaluate Research in Education 8th Edition. New York: Mc Graw Hill.

[4]. Hake, Richard R. (1999). American Educational Research Association's Division D, Measurement and Research Methodology: Analyzing Change/Gain Scores. http://www.psysicsindiana.edu/sdi/AnalyzingChange-Gain.pdf.

[5]. Mahanal, Susriyati, dkk. 2009. Pendidikan Lingkungan Hidup Untuk Sekolah Dasar Kelas V Jilid 5. Malang: Pusat Penelitian Lingkungan Hidup Lembaga Penelitian Universitas Negeri Malang.

[6]. Ratumanan, T. G., \& Laurens, T. (2011). Penilaian Hasil Belajar pada Tingkat Satuan Pendidikan Edisi 2. Surabaya: Unesa University Press.

[7]. Riduwan. (2012). Skala Pengukuran VariabelVariabel Penelitian. Bandung: Alfabeta.

[8]. Utaya, Sugeng, dkk. 2009. Pendidikan Lingkungan Hidup Untuk Sekolah Dasar Kelas VI Jilid 6. Malang: Pusat Penelitian Lingkungan Hidup Lembaga Penelitian Universitas Negeri Malang.

[9]. Yurimoto, Katsumi. 2017. Oh, ternyata Kita Bisa Melakukan Kegiatan 3R (Reduce, Reuse, dan Recycle) untuk Mengurangi Sampah!. Jakarta: PT Gramedia Pustaka Utama. 